\title{
tRNA intergenic spacers reveal polymorphisms diagnostic for Xanthomonas albilineans
}

\author{
Rhonda J. Honeycutt, ${ }^{1}$ Bruno W. S. Sobral ${ }^{1}$ and Michael McClelland ${ }^{2}$
}

Author for correspondence: Rhonda J. Honeycutt. Tel: +1 619535 5491. Fax: +1 6195355472. e-mail: Rhoneycutt@lifsci.sdsu.edu

1 Center for the Application of Molecular Biology to International Agriculture, CAMBIA Americas, 11099 North Torrey Pines Road, Ste. 295, La Jolla, CA 92037, USA

2 Sidney Kimmel Cancer Center, 11099 North Torrey Pines Road, Ste. 290, La Jolla, CA 92037, USA

\begin{abstract}
A PCR-based detection system was developed for Xanthomonas albilineans, a pathogen of sugarcane, and other related xanthomonads, using the conserved sequence of two adjacent tRNA genes and the variable length and sequence of the spacer region between them. An appropriate region was identified as follows: tRNA genes with the same anticodon from a wide variety of bacteria were aligned and the most frequent base at each position was chosen to derive primers that would anneal to the gene in either orientation. Pairs of such primers were screened against various $X$ anthomonas species and members of related genera using PCR at low to moderate annealing stringency. A subset of these pairs of tRNA consensus primers gave one or more PCR products which generally displayed interspecific length variability. The primer pair 5'-3' tRNA ${ }^{a l a}$ and $3^{\prime}-5^{\prime}$ tRNA $A^{110}$ showed interspecific length polymorphisms between $X$. albilineans and all other Xanthomonas species examined. These PCR products were cloned and sequenced from four isolates of $X$. albilineans and four isolates from different pathovars of $X$. campestris, and the spacer length variation confirmed. Specific tRNA gene primers were derived from the tRNA gene sequences. These primers yielded a PCR product of a characteristic length within most Xanthomonas species and pathovars tested. When a primer that projected from tRNA ${ }^{\text {ala }}$ into the $3^{\prime}$ end of the

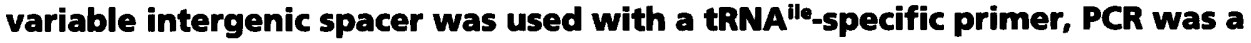
very sensitive diagnostic test for $X$. albilineans-infected sugarcane and gave no product or only a faint product with other species of bacteria. The specificity of this PCR-based detection system was further enhanced by a nested PCR reaction that took advantage of the fact that the tRNAle-tRNAile region was found to be embedded in a 165 rRNA-23S rRNA gene spacer. By amplifying the region between the 16S rRNA gene and tRNA ${ }^{110}$ or between the tRNA ${ }^{\text {ala }}$ and the 235 rRNA gene, the subsequent nested PCR product was shown to be $X$. albilineans-specific.
\end{abstract}

Keywords: Xanthomonas albilineans, tRNA, polymerase chain reaction, phytopathogen, leaf scald disease, sugarcane

\section{INTRODUCTION}

Xanthomonas are Gram-negative bacteria in the Pseudomonadaceae family of the Gracilicutes. All Xanthomonas species are plant pathogens. Currently six Xanthomonas species are recognized: $X$. albilineans, $X$. axonopodis, $X$. campestris, $X$. fragariae, $X$. oryzae and $X$. populi. $X$. campestris has the most complex taxonomic structure, being subdivided into over 140 pathovars specific for

The GenBank accession numbers for the nucleotide sequence data reported in this paper are L42971-L42976. certain plant hosts or diseases (Vauterin et al., 1990). This requires further taxonomic clarification as recent molecular evidence based on DNA homologies indicates that $X$. campestris is not a single species (Palleroni $e t$ al., 1993; Hildebrand et al., 1990).

$X$. albilineans is the causal agent of leaf scald disease in sugarcane, a systemic disease characterized by chronic and acute phenotypes (reviewed by Ricaud \& Ryan, 1989). In addition, under certain environmental conditions, latent infections can become fulminant. Current methods for detection rely on isolation of pure cultures onto selective media (Davis et al., 1994a) or immunoassays of tissue 
extracts (Comstock \& Irey, 1992). Serotyping (Rott et al., 1994) and RFLP fingerprints and electrophoretic karyotypes from PFGE (Davis et al., 1994b) have revealed variation within $X$. albilineans. These methodologies, useful for detection or identification of some isolates, do not provide a sufficient combination of sensitivity, speed, reliability and high output to serve as a diagnostic test for $X$. albilineans. Such a tool would facilitate ecological studies as well as quarantine assessment.

PCR-based tools have been developed that are useful in determining genomic variation, e.g. arbitrarily primed PCR (APPCR; Welsh \& McClelland, 1990; Williams et al., 1990) and rep-PCR (Versalovic et al., 1991). Welsh et al. (1992) used APPCR characters to distinguish phyletic groups within Borrelia burgdorferi, and rep-PCR fingerprinting has been demonstrated as a potential means of identifying Xanthomonas and Pseudomonas strains (Louws $e t$ al., 1994). Leite et al. (1994) combined specific PCR primers designed from a $h r p$ gene, followed by restriction digestion of amplified products to reveal variation among some Xanthomonas strains that are pathogenic on plants. The $b r p$-specific primers did not produce products in $X$. albilineans or in all pathovars of $X$. campestris.

Most tRNA genes in eubacteria are found in tandem clusters with genes separated by a short spacer region. Previously, Welsh \& McClelland (1991) had designed pairs of PCR primers based on a consensus sequence for all Bacillus tRNAs. At low to moderate annealing stringency, these primers generate fingerprints consisting mainly or exclusively of products derived from these tandem arrays, with products generally spaced by about one tRNA gene repeat unit (Welsh \& McClelland, 1991). If a number of species are compared, it is possible to identify repeats that are of different lengths due to interspecific variations in the intergenic spacer regions between tRNA genes (McClelland et al., 1992; Welsh \& McClelland, 1992). These authors speculated that the sequence and order of tRNA genes probably evolves very slowly compared to neutral DNA or protein coding regions, so primers are likely to match perfectly with genes in all strains of a species or even genus. However, variation in intergenic spacer length probably occurs almost as quickly as in neutral DNA. This results in variations on the length of the PCR product which may often be diagnostic for particular species or sub-species. Consensus tRNA primers have since been used to assess genetic variability and phylogenetic relationships among isolates of Pseudomonas solanacearum (Seal et al., 1992), Acinetobacter (Wiedmann-Al-Ahmad et al., 1994) and entomopathogenic fungi (Tigano-Milani et al., 1995a, b).

When products polymorphic in length are cloned and sequenced, new specific tRNA-gene-based PCR primers can be derived. The resulting high stringency PCR products that span the intergenic length polymorphisms are diagnostic markers that define a group of species by the presence of a PCR product and identify taxonomic subsets of these organisms by virtue of the size of the PCR product (McClelland et al., 1992; Welsh \& McClelland, 1992). Here we have used a further refinement of this approach based on consensus primers derived from aligning homologous tRNAs (that share the same anticodon) from all eubacteria. These primers have been used to distinguish between members of the genus Xanthomonas at various taxonomic levels.

\section{METHODS}

Bacterial strains, leaf samples and DNA extraction. Bacterial strains used in this study are listed in Table 1. Samples from ATCC or ICPB were received as bacterial cultures; all other samples were received as genomic DNA. Strains were grown in either Media 3 or Media 825 (as recommended by ATCC) or YDCP media for strains received from ICPB. Genomic DNA was isolated according to standard protocols (Ausubel et al., 1987), and quantified on agarose gels. Alternatively, single bacterial colonies were boiled in $500 \mu \mathrm{l}$ sterile water for $10 \mathrm{~min}$, then centrifuged at 12000 r.p.m. for $5 \mathrm{~min}$ and the supernatant used as a template for PCR.

Leaf samples of sugarcane cultivar LCP82-89, as well as X. albilineans isolated from LCP82-89 grown in the field, were kindly supplied by Michael Grisham (USDA-ARS, Houma, LA, USA). Symptomatic and asymptomatic leaves were fixed in ethanol. Sectors of leaf blade (about $0.4 \mathrm{~g}$ wet wt) were excised and DNA extracted using a CTAB-based protocol (Murray \& Thompson, 1980). DNA preparations were quantified by spectrophotometry and used as templates for PCR.

PCR primers. Primers were designed using four different criteria.

(a) Consensus tRNA primers made after aligning all Bacillus subtilis tRNAs (Welsh \& McClelland, 1991): 'T5A, 5' AGTCCGGTGCTCTAACCAACTGAG 3' and T3B, 5' AGGTCGCGGGTTCGAATCC 3'.

(b) Each set of 21 homologous eubacterial tRNAs were aligned separately (GenBank version 11). From each of these alignments two PCR primers were derived. Details and nomenclature are given in Results. Of the 42 possible primers, six consensus anticodon-specific tRNA primers were used in this study: phenylalanine tRNA (FEU), 5' TTGGKAGAGCRWYRGACTGAA 3'; tryptophan tRNA (WEU), 5' TGGTAGARCRSMGGTCTCCA $3^{\prime}$; alanine tRNA (AEU), 5' GYTGGKAGAGCRCCTGCYTTG $3^{\prime}$; initiator methionine tRNA (iMEL), $5^{\prime}$ CCKRSGACCTWWGGGTTATG $3^{\prime}$; isoleucine tRNA (IEL), 5' GAACYWSYGACCTYACSCTTATC $3^{\prime}$ and proline tRNA (PEL), 5' GAACCTSCGACCCMYYGGTCCCA 3'.

(c) Genus- and species-specific primers were designed using sequence alignment of AEU + IEL amplified PCR products from four isolates of $X$. albilineans and four isolates of $X$. campestris pathovars with bacterial and plant tRNAs in GenBank. These primers were named for their relative positions on tRNA ${ }^{\text {ala }}$ and tRNA ${ }^{\text {ile }}$ : Ala1, 5' TTTGCAAGCAGGGGGTCGTC 3'; Ala2, 5' TCGTCGGTTCGATCC CGAC 3'; Ala4, 5' CCCGACTGGCTCCACCACTG 3'; Ile1, 5' AGGGGTGCGCTCTAACCAC $3^{\prime}$ and Ile2, 5' CCTTATCAGGGGTGCGCTC 3'.

(d) Primers for ribosomal RNA sequences from conserved regions at the $3^{\prime}$ end of the $16 \mathrm{~S}$ rRNA gene and $5^{\prime}$ end of the $23 \mathrm{~S}$ rRNA gene (D. Ralph \& M. McClelland, CIBR, unpublished data) were: $16 \mathrm{~S}$ uni1330, 5' GTTCCCGGGCCTTGTACACAC $3^{\prime}$ and $23 S$ uni322anti, 5' GGT'TCT'TTTCACCT'T'TCCCTC $3^{\prime}$.

All primers used in this study were synthesized by Genosys.

PCR conditions. Pairs of consensus tRNA primers were initially screened using two X. albilineans (CTC193 and ATCC 29186) isolates and $X$. campestris pv. bolcicola at two template concen- 
Table 1. Xanthomonas and Pseudomonas isolates used in this study

Abbreviations: ATCC, American Type Culture Collection, Rockville, MD, USA; CTC, Copersucar, Piracicaba, Brasil; ICPB, International Collection of Phytopathogenic Bacteria, Berkeley, CA, USA; MSRI, Mauritius Sugar Industry Reseach Institute, Reduit, Mauritius; NCPPB, National Collection of Plant Pathogenic Bacteria, Harpenden, UK.

\begin{tabular}{|c|c|c|c|c|}
\hline Species & Strain & Host & Origin & Supplier \\
\hline \multicolumn{5}{|l|}{ Xanthomonas } \\
\hline$X$. albilineans & CTC193 & Saccharum offcinarum & Brazil & CTC \\
\hline$X$. albilineans & CTC293 & Saccharum officinarum & Brazil & CTC \\
\hline$X$. albilineans & CTC393 & Saccharum officinarum & Brazil & CTC \\
\hline$X$. albilineans & CTC493 & Saccharum officinarum & Brazil & CTC \\
\hline$X$. albilineans & MSRI3201 & Saccharum officinarum & Mauritius & MSRI \\
\hline$X$. albilineans & MSRI3284 & Saccharum officinarum & Mauritius & MSRI \\
\hline$X$. albilineans & MSRI3295 & Saccharum officinarum & Mauritius & MSRI \\
\hline$X$. albilineans & MSRI2905 & Saccharum officinarum & Mauritius & MSRI \\
\hline$X$. albilineans & $\mathrm{XaOD} 1$ & Saccharum officinarum & Florida & $\begin{array}{l}\text { J. Comstock, } \\
\text { USDA-ARS, FL }\end{array}$ \\
\hline$X$. albilineans & $\mathrm{XaOD} 2$ & Saccbarum officinarum & Florida & $\begin{array}{l}\text { J. Comstock, } \\
\text { USDA-ARS, FL }\end{array}$ \\
\hline$X$. albilineans & $\mathrm{XaCP} 2$ & Saccbarum officinarum & Florida & $\begin{array}{l}\text { J. Comstock, } \\
\text { USDA-ARS, FL }\end{array}$ \\
\hline$X$. albilineans & $\mathrm{XaCP} 3$ & Saccbarum officinarum & Florida & $\begin{array}{l}\text { J. Comstock, } \\
\text { USDA-ARS, FL }\end{array}$ \\
\hline$X$. albilineans & $\mathrm{XaCP} 4$ & Saccbarum officinarum & Florida & $\begin{array}{l}\text { J. Comstock, } \\
\text { USDA-ARS, FL }\end{array}$ \\
\hline$X$. albilineans & LA334 & Saccbarum officinarum & Louisiana & $\begin{array}{l}\text { M. Grisham, } \\
\text { USDA-ARS, LA }\end{array}$ \\
\hline$X$. albilineans subsp. paspali & ATCC 29186 (NCPPB 208) & Paspalum dilatatum & Mauritius & ATCC \\
\hline$X$. axonopodis & ATCC 19312 (NCPPB 457) & Axonopus scoparius & Colombia & ICPB \\
\hline$X$. campestris pv. badrii & ATCC 11672 (NCPPB 571) & Xanthium strumarium & India & $\begin{array}{l}\text { M. Simcox, } \\
\text { Stratagene }\end{array}$ \\
\hline$X$. campestris pv. campestris & $\begin{array}{l}\text { B293 (A TCC 22913, } \\
\text { NCPPB 528) }\end{array}$ & $\begin{array}{l}\text { Brassica oleracea } \\
\text { var. gemmifera }\end{array}$ & $?$ & $\mathrm{ICPB}$ \\
\hline$X$. campestris pv. celebensis & $\begin{array}{l}\text { XC145 (ATCC 19045, } \\
\text { NCPPB 1832) }\end{array}$ & Musa sp. & New Zealand & $\mathrm{ICPB}$ \\
\hline X. campestris pv. bolcicola & ATCC 13461 & Holcus sp. & $?$ & M. McClelland \\
\hline X. campestris pv. malvacearum & ATCC 9924 & Gossypium & $?$ & $\begin{array}{l}\text { M. Simcox, } \\
\text { Stratagene }\end{array}$ \\
\hline$X$. campestris pv. manibotis & 7AS1 & Manibot esculenta & $?$ & $\begin{array}{l}\text { M. Simcox, } \\
\text { Stratagene }\end{array}$ \\
\hline$X$. campestris pv. pelargonii & XP15 (ATCC 8721) & Pelargonium sp. & $?$ & ICPB \\
\hline$X$. campestris pv. phaseoli & XP200 (NCPPB 1680) & $?$ & $?$ & ICPB \\
\hline$X$. campestris pv. taraxaci & $\begin{array}{l}\text { XT11 (ATCC 19318, } \\
\text { NCPPB 940) }\end{array}$ & Taraxacum kok-sagbyz & USA & $\mathrm{ICPB}$ \\
\hline$X$. campestris pv. undulosa & ATCC 35935 (NCPPB 2821) & Triticum turgidum & $?$ & ICPB \\
\hline$X$. campestris pv. vasculorum & ATCC 13901 & Saccharum officinarum & Puerto Rico & ATCC \\
\hline$X$. fragariae & Strain 305 & Fragaria sp. & $?$ & ICPB \\
\hline X. oryzae pv. oryzae & ATCC 35933 (NCPPB 3002) & Oryza sativa & $?$ & ICPB \\
\hline$X$ oryzae pv. oryzicola & XO111 & Oryza sp. & $?$ & ICPB \\
\hline$X$. populi & XP233 (NCPPB 2961) & Populus balsamifera & The Netherlands & ICPB \\
\hline \multicolumn{5}{|l|}{ Pseudomonas } \\
\hline P. syringae pv. lapsa & ATCC 10859 & $?$ & $?$ & ATCC \\
\hline P. rubrisubalbicans & ATCC 19308 (NCPPB 1027) & Saccharum officinarum & $?$ & ATCC \\
\hline \multicolumn{5}{|l|}{ Acidovorax } \\
\hline A. avenae subsp. avenae & ATCC 19307 (NCPPB 920) & Saccharum officinarum & $?$ & ATCC \\
\hline A. avenae subsp. avenae & ATCC 12530 & $?$ & $?$ & ATCC \\
\hline Stenotrophomonas maltophilia & ATCC 13637 & Homo sapiens & $?$ & ICPB \\
\hline Bacillus amyloliquefaciens & $\mathrm{H}$ & $?$ & $?$ & ATCC \\
\hline Escherichia coli & RY13 & & & M. McClelland \\
\hline Streptomyces achromogenes & ATCC 12767 & & & M. McClelland \\
\hline Streptomyces albus & G & & & M. McClelland \\
\hline Fusobacterium nucleatum & $\mathrm{D}$ & & & M. McClelland \\
\hline Rbodobacter spaeroides & & & & M. McClelland \\
\hline Norcardia aerocolonigenes & A TCC 23870 & & & M. McClelland \\
\hline Flavobacterium okeanokoites & ATCC 33414 & & & M. McClelland \\
\hline Arthrobacter luteus & ATCC 21606 & & & M. McClelland \\
\hline
\end{tabular}


(a)

\begin{tabular}{|c|c|}
\hline \multirow{2}{*}{\multicolumn{2}{|c|}{ Itris pv. badrii }} \\
\hline & \\
\hline Acholeplasma laidlawii & \\
\hline Acholeplasma laidlawii & \\
\hline Bartonella bacilliformis & \\
\hline Blastocrithidia culicis & \\
\hline Bacillus spp. & \\
\hline Bacillus subtilis & \\
\hline Coxiella burnettii & \\
\hline Caulobacter crescentus & \\
\hline Campylobacter jejuni & \\
\hline Escherichia coli & \\
\hline Enterococcus faecalis & \\
\hline Enterococcus hirat & \\
\hline Kinetoplastibacterium crithidii & \\
\hline Lactococcus tactis & \\
\hline Leuconostoc oenos & \\
\hline Mycoplasma capricolum & \\
\hline Mycoplasma mycoides & \\
\hline Neisseria meningitidis & \\
\hline Pseudomonas cepacia & \\
\hline Psoudomonas gladioli & \\
\hline Pseudomonas mallei & \\
\hline Pseudomonas mendocina & \\
\hline Pseudomonas mendocina & \\
\hline Pseudomonas pickettii & \\
\hline Pseudomonas pseudoalcallgenes & \\
\hline Rhodobacter sphaeroides & \\
\hline Staphylococcus aurous & \\
\hline Spiroplasma meliferum & \\
\hline Streptococcus pneumoniae & \\
\hline Streptococcus pneumoniae & \\
\hline Thiobacillus ferrooxidans & \\
\hline Stenotrophomonas maltophilia & \\
\hline$X$. albilineans & \\
\hline$X$. albilineans & \\
\hline$X$. albilineans & \\
\hline$X$. albilineans & \\
\hline$X$. campestris pv. malvacearum & \\
\hline$X$. campestris pv. manthotis & \\
\hline$X$. campestris pv. vasculorum & \\
\hline$X$. campestris pv. badrii & \\
\hline
\end{tabular}

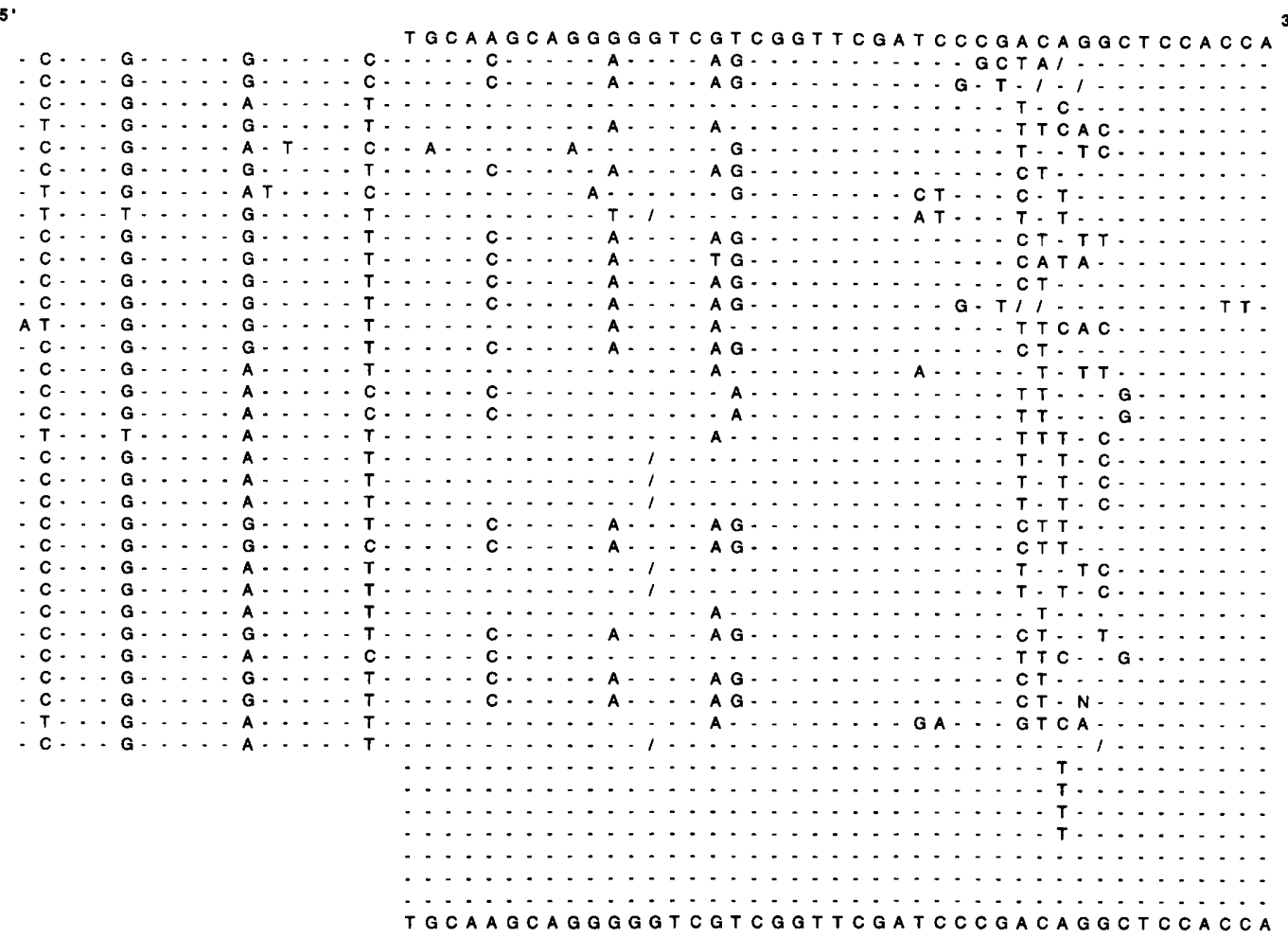

(b)

GYTGGKAGAGCRCCTGCYTTG

\section{Spocies}

$X$ campestris pv. badrii

Acholeplasma laidlawii

Acholeplasma laidlawit

Bartonella bacilliformis

Blastocrithidia culicis

Bacillus subtilis

Bacillus subtlis

Bordetella sp.

Coxiella burnettif

Escherichia coli

Escherichia coll

Kinetoplastibacterium crithidii

Mycoplasma -like

Mycoplasma sp.

Neisseria meningitidis

Psoudomonas aeruginosa

Pseudomonas aeruginosa

Pseudomonas copacia

Pseudomonas fuorescens

Pseudomonas fluorescens

Pseudomonas gladioli

Pseudomonas mallei

Pseudomonas mendocina

Pseudomonas picketti

Pseudomonas pseudoaicaligenes

Rhodopseudomonas marina

Stenotrophomonas maltophilia

$X$. albilineans

$X$. albilineans

$X$. albilineans

$X$. alblineans

$x$. campestris $\rho v$. malvacearum

$X$. campestris $p v$. manihotis

$x$. campestris $\rho v$. vasculorum

$X$. campestris pv. badrii

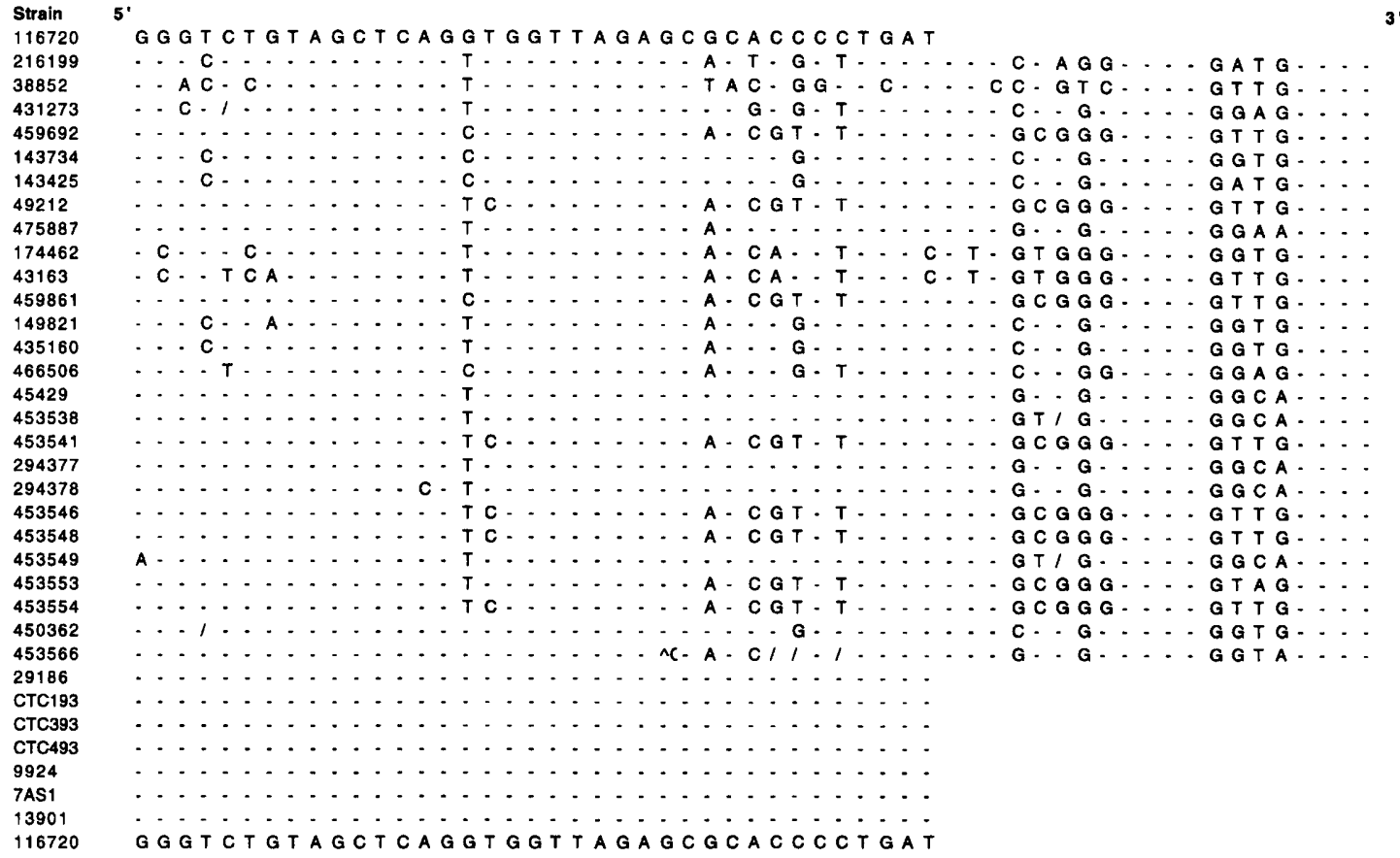

GATAAGSGTYAGGTCYSWYGTTC

Fig. 1. Alanine and isoleucine tRNAs sequences in GenBank (version 11) were aligned using $X$. campestris pv. badrii as the reference sequence. The eubacterial alignments used to generate the AEU and IEL primers are included in the left-most 21 bases of (a) and the right-most 23 bases of (b), respectively. $K=G$ or $T, R=A$ or $G, Y=T$ or $C, S=G$ or $C, W=A$ or $T$. ' $'$ ' represents an identical base, ' $/$ ' represents a deleted base and ' $'$ ' represents an additional base relative to the reference sequence. The new tRNA sequences from AEU + IEL amplification products generated in this study (Fig. 2) are included at the bottom of (a) and (b) as indicated. 
trations in $50 \mu \mathrm{l}$ reactions $[1.25 \mathrm{U}$ AmpliTaq, $1 \times$ Taq buffer, $1.5 \mathrm{mM} \mathrm{MgCl}, 0.2 \mathrm{mM}$ each dNTP, $0.5 \mu \mathrm{M}$ each primer and $5 \mu \mathrm{Ci}(0 \cdot 185 \mathrm{MBq}){ }^{32} \mathrm{P}$-dCTP] for 40 cycles at $94{ }^{\circ} \mathrm{C}$ for $30 \mathrm{~s}$, $50{ }^{\circ} \mathrm{C}$ for $30 \mathrm{~s}$ and $72{ }^{\circ} \mathrm{C}$ for $2 \mathrm{~min}$. Products were resolved on $5 \%$ denaturing polyacrylamide gels with electrophoresis for $2.5 \mathrm{~h}$ at $58 \mathrm{~W}$ constant power. The gels were dried onto Whatman $3 \mathrm{MM}$ paper and exposed overnight on X-Omat AR film.

Specific PCR amplifications using primer pairs developed in this study were performed as above. Some reactions also included $0.5 \mathrm{U}$ PerfectMatch (Stratagene). Cycling parameters were either 40 cycles at $94^{\circ} \mathrm{C}$ for $20 \mathrm{~s}$ and $70^{\circ} \mathrm{C}$ for $20 \mathrm{~s}, 40$ cycles at $94^{\circ} \mathrm{C}$ for $30 \mathrm{~s}, 65^{\circ} \mathrm{C}$ for $30 \mathrm{~s}$ and $72{ }^{\circ} \mathrm{C}$ for $30 \mathrm{~s}$, or 30 cycles at $94^{\circ} \mathrm{C}$ for $20 \mathrm{~s}$ and $65^{\circ} \mathrm{C}$ for $20 \mathrm{~s}$, as indicated in the Figure legends. Products were resolved on $3 \%$ NuSieve (FMC) agarose gels prepared in $1 \times \mathrm{TBE}$ with electrophoresis at $12 \mathrm{~V} \mathrm{~cm}^{-1}$ for $2.5 \mathrm{~h}$. The molecular mass markers (123 bp and $1 \mathrm{~kb}$ ladders) were purchased from Gibco BRL.

Reactions for experiments involving $16 \mathrm{~S}$ uni1330 or $23 \mathrm{~S}$ uni322anti were performed using 40 cycles at $94^{\circ} \mathrm{C}$ for $30 \mathrm{~s}$, $65^{\circ} \mathrm{C}$ for $30 \mathrm{~s}$ and $72{ }^{\circ} \mathrm{C}$ for $1 \mathrm{~min}$.

Reamplification, cloning and sequencing. PCR products from amplifications with AEU + IEL primers were excised from dried gels and eluted overnight at room temperature in $50 \mu \mathrm{l}$ of sterile water, then used as a template for reamplification. The final concentration of reaction components and cycling parameters were as above except 1 and $2 \mu$ l of the eluted products were used as templates. Fifteen microlitres of each reaction was loaded onto a $2 \%$ agarose gel prepared in $0.5 \times \mathrm{TBE}$ and electrophoresis was performed at $12 \mathrm{~V} \mathrm{~cm}^{1}$ for $2.5 \mathrm{~h}$. The remainder of each reaction product was purified by chloroform/ isoamyl alcohol extraction, ethanol-precipitated and cloned.

Reamplified PCR products were blunt-end ligated into pCRScript (Stratagene) and transformed into Escherichia coli XL1-blue MRF' (Stratagene). Clones containing inserts were identified as white colonies from which single-stranded DNA was prepared according to standard protocols, and sequenced using a Sequenase $2.0 \mathrm{kit}$ (USB).

Sequence alignments. Sequences were aligned using GeneWorks software (Intelligenetics) and compared to both bacterial and plant tRNA sequences of GenBank (version 11) (Fig. 1).

\section{RESULTS AND DISCUSSION}

\section{Primer design}

tRNA genes in bacteria occur in mixed cistrons of direct tandem repeats (e.g. Jinks-Robertson \& Nomura, 1987). Here, we present a variation on the tRNA gene PCR fingerprinting strategy of Welsh \& McClelland (1991). This variation uses primers derived from particular tRNA anticodon types rather than a consensus of all tRNAs. These primers were designed so that two or three bases at the $3^{\prime}$ end are the conserved anticodon loop (underlined in primer sequence). Thus, for example, we aligned all known eubacteria alanine tRNAs, anticodon TGC, to derive a primer, AEU, oriented $5^{\prime}-3^{\prime}$ relative to transcription (the left-most 21 bases in Fig. 1a). Another primer oriented in the opposite direction and also ending with its $3^{\prime}$ end at the anticodon was designed for tRNA ala but is not shown. Fig. 1(b) shows the alignment of the

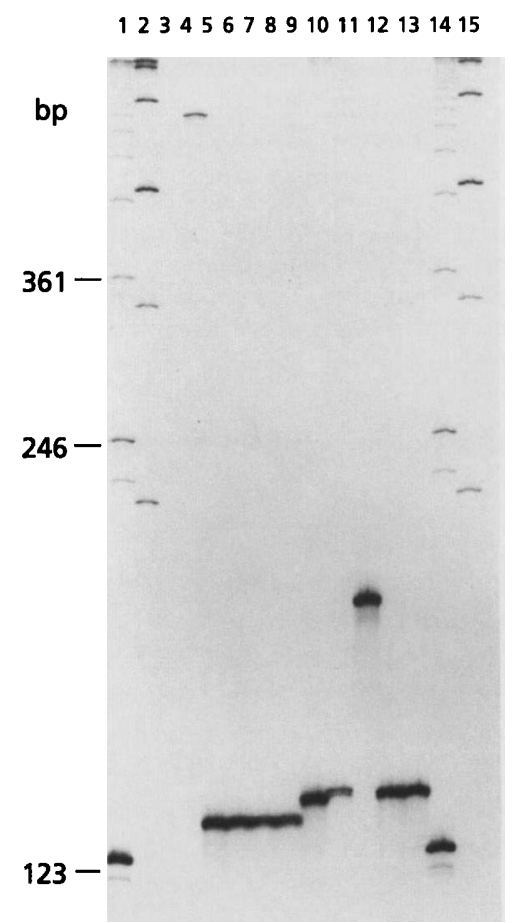

Fig. 2. Amplification products of Xanthomonas species using tRNA consensus primers AEU (alanine) + IEL (isoleucine) and $5 \mathrm{ng}$ bacterial DNA resolved on a $5 \%$ denaturing polyacrylamide gel. Lanes: 1, 123 bp standard; 2, 1 kb standard; 3, no DNA control; 4, Bacillus amyloliquefaciens $\mathrm{H}$; 5-8 $X$. albilineans strains (ATCC 29186, CTC193, СTC393 and CTC493, respectively); 9, X. campestris pv. vasculorum (ATCC 13901); 10, $X$. campestris pv. malvacearum (ATCC 9924); 11, X. campestris pv. badrii (ATCC 11672); 12, X. campestris pv. holcicola (ATCC 13461); $13, X$. campestris pv. manihotis (7AS1); 14, 123 bp standard; 15, 1 kb standard.

isoleucine consensus anticodon-specific primer IEL in the $3^{\prime}-5^{\prime}$ orientation relative to transcription.

Names for these primers consist of the one letter amino acid code, ' $E$ ' for eubacteria, then ' $U$ ' or ' $L$ ' for 'upper' and 'lower' strands of the gene. $U$ and $L$ indicate primers that are oriented $5^{\prime}-3^{\prime}$ or $3^{\prime}-5^{\prime}$ in the consensus tRNA gene, respectively.

Consensus anticodon-specific primers derived from two particular tRNA types used in combinations (one primer oriented $5^{\prime}-3^{\prime}$ and the other $3^{\prime}-5^{\prime}$ ) will yield PCR products only if that particular combination of tRNAs occurs in the correct order in at least one of the tRNA gene tandem arrays. It can reasonably be speculated that once such a combination is found in one species, then it almost certainly occurs in most or all other species in the same genus (Jinks-Robertson \& Nomura, 1987; Welsh \& McClelland, 1992; McClelland et al., 1992). When PCR products amplified from different species are then visualized side-by-side using PAGE, intergenic length polymorphisms may be revealed. These PCR products can be cloned, sequenced and specific PCR primers can be derived, as required to meet particular taxonomic criteria. 


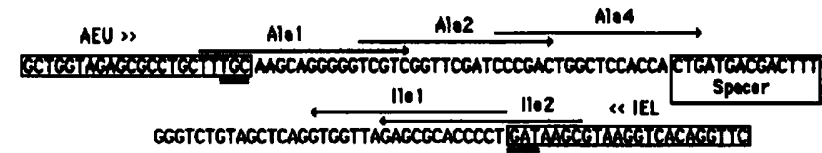

Fig. 3. Sequence of AEU+IEL PCR product from $X$. albilineans. The $A E U$ and IEL primer sequences are boxed and the anticodon underlined. The location and orientation of primer sequences used in this study are shown.

\section{Detection of a polymorphism among Xanthomonas species}

tRNA consensus primers were screened in pairwise combinations, oriented so that a productive PCR amplification could take place. Primers were chosen that would hybridize to opposite strands of the tRNA gene sequences. Consensus anticodon-specific tRNA primers (see Methods) and the consensus universal tRNA primers T5A and T3B (Welsh \& McClelland, 1991; Welsh et al., 1992) were used in a total of 13 combinations. Some combinations revealed complex patterns. For example, for the $X$. albilineans and $X$. campestris isolates tested, primers T5A + T3B gave three prominent PCR products, each probably a multiple of $t R N A$ genes from the same or different tRNA gene clusters (data not shown). Other primer combinations gave single or no products within the Xanthomonas species tested. For example, the AEU + IEL anticodon-specific primers for alanine and isoleucine tRNAs, respectively, resulted in single products of different lengths for $X$. albilineans and $X$. campestris isolates (Fig. 2) as compared to Pseudomonas rubrisubalbicans, Pseudomonas syringae pv. lapsa or Acidovorax avenae subsp. avenae isolates which gave multiple products (data not shown). With the exception of pv. badrii, X. campestris pathovars gave products of a similar length, which were distinct from those found in $X$. albilineans isolates. Thus, the products generated with this particular pair of primers were chosen for further study because a potential $X$. albilineans-specific length polymorphism was present between an alanine and isoleucine tRNA gene, which would meet our objective of a PCR-based diagnostic test.
Clones of the AEU + IEL products were obtained in both orientations for three isolates of $X$. albilineans, one isolate of $X$. albilineans subsp. paspali, and one isolate each of $X$. campestris pv. badrii, pv. malvacearum, pv. manibotis and pv. vasculorum. The complete sequence of the $X$. albilineans tRNA ${ }^{\text {ala }}-$ tRNA $^{\text {ile }}$ region is shown in Fig. 3, along with the primers designed to amplify subsequences of this region. All sequences were divided into three sections; alignments of all known bacterial tRNA ${ }^{\text {ala }}$ genes, including the one we have sequenced here, are shown in Fig. 1(a) and all tRNA ${ }^{\text {ile }}$ genes in Fig. 1(b). The spacers sequenced in this study are presented in Table 2 .

All $X$. albilineans isolates included a spacer region of 14 bases while the spacer region in the $X$. campestris pathovars varied in length from 17 to 66 bases (Table 2). The $66 \mathrm{bp}$ spacer sequence from $X$. campestris pv. badrii shared over $60 \%$ sequence identity with the 73 bp spacer between these genes in Stenotrophomonas maltophilia (S. D. Tyler, C. A. Strathdee, W. M. Johnson \& K. P. Rozee, unpublished), synonym $X$. maltophilia (Palleroni \& Bradbury, 1993). Alignments of $t R N A^{\text {ala }}$ and tRNA ${ }^{\text {ile }}$ sequences to other bacterial sequences found in GenBank are shown in Fig. 1. Based on these alignments, additional primers, Ala1, Ala2, Ala4, Ile1 and Ile2, were designed (Fig. 3). All of these primers, except Ala4, were positioned in such a way that they had a perfect match in the tRNAs of Xanthomonas. Because the tRNAs are well conserved between genera, these primers also exhibited a good, but imperfect, match with the tRNAs from known Pseudomonas and related species. In contrast, Ala4+Ile1 and Ala4+Ile2 was predicted to yield an approximately 70 bp product only in $X$. albilineans because the $3^{\prime}$ end of Ala4 lies within the spacer region, a sequence that may be unique to $X$. albilineans (Fig. 3 and Table 2).

\section{Length polymorphisms revealed among Xanthomonas species}

PCR using the primer pairs Ala1 + Ile2 or Ala2 + Ile2 was performed on an array of isolates including representatives of six Xanthomonas species, five DNA homology groups within X. campestris (Palleroni et al., 1993; Vauterin et al., 1990), two Pseudomonas species, one

Table 2. tRNA ${ }^{\text {ala_-tRNA }}{ }^{\text {ile }}$ spacer sequences from the AEU + IEL amplification products shown in Fig. 2

\begin{tabular}{|c|c|c|c|}
\hline Species & Strain & $\begin{array}{c}\text { Spacer } \\
\text { length (bp) }\end{array}$ & Sequence $\left(5^{\prime}-3^{\prime}\right)$ \\
\hline$X$. campestris pv. badrii & ATCC 11672 & 66 & $\begin{array}{r}\text { GTACGCGGAT CCTTCCGCAA } \\
\text { GAGCCCGCAC ATCCATGTGC } \\
\text { GCACTTTTAT GGAAGCGCAA GACTTT }\end{array}$ \\
\hline$X$. campestris pv. vasculorum & ATCC 19301 & 19 & TAT TGAGTGAAAA GACTTC \\
\hline$X$. campestris pv. malvacearum & ATCC 9924 & 18 & TT TGAGTGAAAC GACTTT \\
\hline$X$. campestris pv. manibotis & 7AS1 & 17 & T TTGAGTGAAA CACTTT \\
\hline$X$. albilineans & ATCC 29186 & 14 & CTGAGGAC GACATT \\
\hline$X$. albilineans & CTC193 & 14 & CTGATGAC GACTTT \\
\hline$X$. albilineans & СТC393 & 14 & CTGATGAC GACTTT \\
\hline X. albilineans & CTC493 & 14 & CTGATGAC GACTTT \\
\hline
\end{tabular}




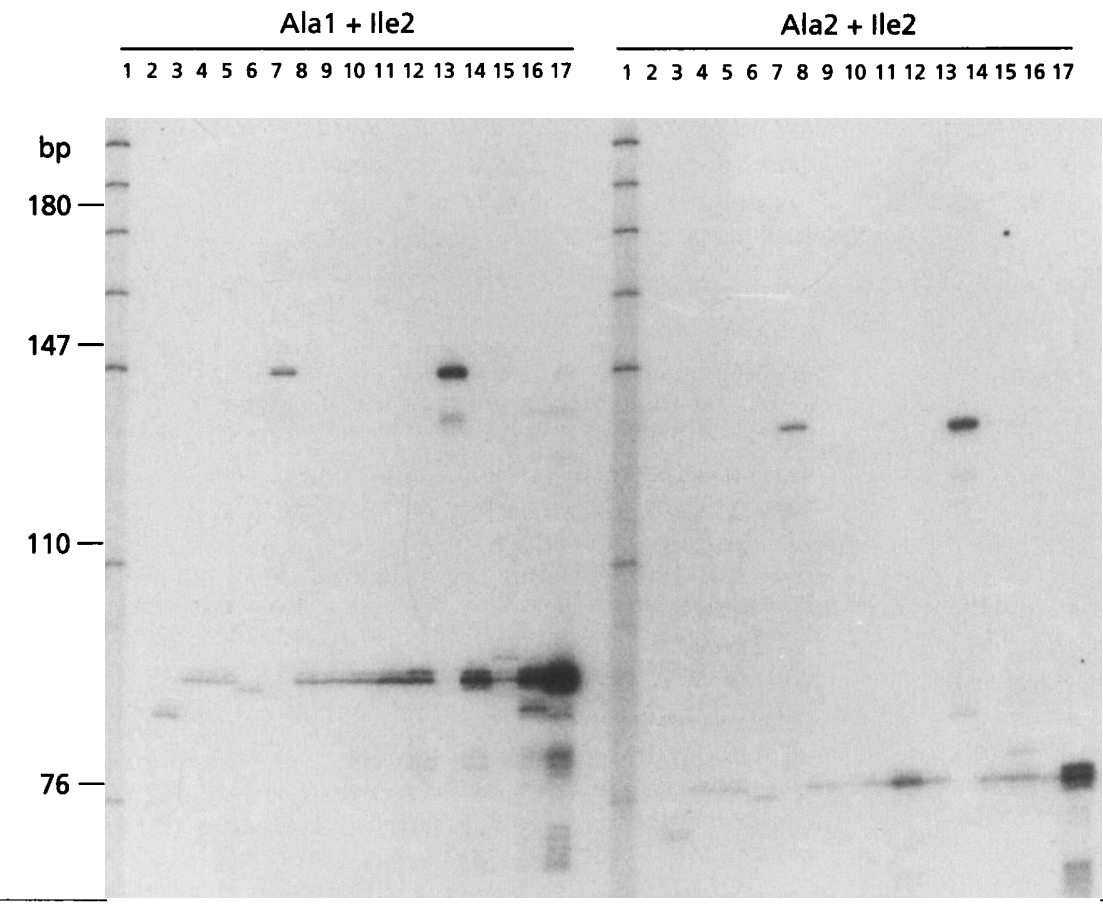

Fig. 4. Length polymorphisms produced using Ala1 + lle2 and Ala2 + lle2 primers for representative Xanthomonas, Pseudomonas, Acidovorax and Stenotrophomonas isolates. Lanes: 1, Mspl-digested pBR322 DNA; 2 , no DNA control; $3, X$ albilineans; $4, X$. axonopodis; $5, X$. campestris pv. campestris; $6, X$. campestris pv. phaseoli; $7, X$. campestris pv. undulosa; $8, X$. oryzae pv. oryzicola; $9, X$. campestris pv. pelargonii; 10 , $X$. campestris pv. celebensis; $11, X$. campestris pv. vasculorum; $12, X$. fragariae; 13 , S. maltophilia; $14, X$. oryzae pv. oryzae; $15, A$. avenae; $16, P$. rubrisubalbicans; $17, P$. syringae pv. lapsa. Reactions were as described in Methods and included PerfectMatch and about $1 \mathrm{ng}$ bacterial genomic DNA. The thermal profile was $94^{\circ} \mathrm{C}$ for $30 \mathrm{~s}, 65^{\circ} \mathrm{C}$ for $30 \mathrm{~s}$ and $72{ }^{\circ} \mathrm{C}$ for $30 \mathrm{~s}$ for 40 cycles. Products were resolved on a $6 \%$ denaturing polyacrylamide gel.

Acidovorax and one Stenotrophomonas species. Similar patterns of PCR products were observed among isolates for both primer pairs (Fig. 4).

Length polymorphisms found in $X$. albilineans and $S$. maltopbilia isolates were distinct from those of other Xanthomonas species The length of the product observed in $X$. campestris pv. undulosa was greater than for other $X$. campestris pathovars, and was similar in size to the $S$. maltophilia product. These data suggest that $X$. campestris may be comprised of more than one species, as noted by Hildebrand et al. (1990) based on DNA:DNA hybridization studies, assuming that $\mathrm{tRNA}$ spacer length is species-specific.

\section{A potential diagnostic test for $X$. albilineans}

Sensitivity. For quarantine-testing, the sensitivity of the PCR reactions is important, especially for $X$. albilineans because there can be a latency phase in the host (Ricaud \& Ryan, 1989). The sensitivity of PCR using the potentially $X$. albilineans-specific primer pair $\mathrm{Ala} 4+\mathrm{Ile} 2$ was determined by titration of the bacterial DNA template in the presence of an excess of plant genomic DNA. For this study, purified genomic DNA from X. albilineans CTC193, at $30 \mathrm{ng}, 3 \mathrm{ng}, 0.3 \mathrm{ng}, 30 \mathrm{pg}, 3 \mathrm{pg}$ and $0.3 \mathrm{pg}$ per reaction was mixed with $50 \mathrm{ng}$ sugarcane genomic DNA. A $70 \mathrm{bp}$ product was observed for all $X$. albilineans + sugarcane templates tested, while no product was observed in the sugarcane-only control reaction (data not shown). This ability to detect approximately 180 genomes (calculated assuming a genome size of $5 \times 10^{6} \mathrm{bp}$ ) is typical of PCR. Given that most bacteria contain more than one copy of the genome, less than 180 bacterial cells can probably be detected using this method.

Although these experiments used mixtures of purified genomic DNA, the results indicate that PCR with these primers is much more sensitive than most immunological methods. Even the most sensitive monoclonal antibody protocols require bacteria in culture to reach sensitivities of 5000 cells (e.g., Tsai et al., 1990). In infected sugarcane material, only levels of $X$. albilineans above $100000 \mathrm{cfu}$ $\mathrm{ml}^{-1}$ can be detected (Comstock \& Irey, 1992).

$\mathrm{Ala} 4+\mathrm{Ile} 2$ was also useful in detecting $X$. albilineans in sugarcane tissues. DNA was extracted from mature leaves of field-grown plants inoculated with $X$. albilineans and from plants not infected by this bacterium. Templates of $150,15,1.5$ and $0.15 \mathrm{ng}$ DNA from asymptomatic leaf tissue and $180,18,1.8$ and $0.18 \mathrm{ng}$ DNA from symptomatic leaf tissue were used in PCR with Ala4 + Ile2 (Fig. 5). Even after only 30 cycles of PCR, the $70 \mathrm{bp}$ product was observed in the symptomatic leaf samples with template masses of 180 and $18 \mathrm{ng}$; the $1.8 \mathrm{ng}$ template yielded a very faint band not visible in reproductions (Fig. 5) but was prominent at 40 cycles (data not shown). Onehundred-and-eighty nanograms of DNA represented a $5 \mathrm{mg}$ sample of leaf. A $70 \mathrm{bp}$ product was also observed in reactions of $X$. albilineans isolate LA334 cultured from the symptomatic leaves. The amount of $X$. albilineans in this sample has been quantified as $10 \%$ by mass and is detectable down to $1000 \mathrm{X}$. albilineans genomes in a $12 \mathrm{pg}$ sample of total infected sugarcane DNA from $0.5 \mu \mathrm{g}$ leaf (R. J. Honeycutt \& M. McClelland, unpublished data). Incorporation of a radioactive nucleotide during PCR allowed even more sensitive detection (data not shown).

When PerfectMatch is included in the reaction, a faint product of about $250 \mathrm{bp}$ is observed only in lanes that give a $70 \mathrm{bp}$ product (Fig. 5). This $250 \mathrm{bp}$ product requires both the Ala4 and the Ile2 primers and is not seen when PerfectMatch is omitted (data not shown). PerfectMatch is a DNA binding protein prepared from 


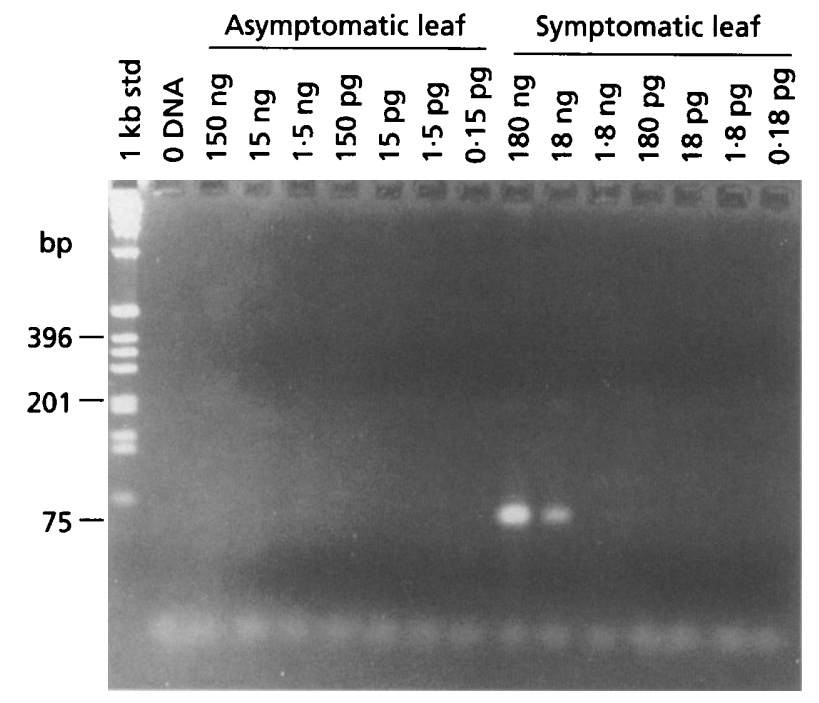

Fig. 5. PCR amplification from the DNA of sugarcane infected with $X$. albilineans (symptomatic) and uninfected sugarcane (asymptomatic) using the primer pair Ala4 and Ile2. DNA template concentrations are as annotated. Reactions were as described in Methods and included PerfectMatch. The thermal profile was $94{ }^{\circ} \mathrm{C}$ for $20 \mathrm{~s}$ and $65^{\circ} \mathrm{C}$ for $20 \mathrm{~s}$ for 30 cycles.

E. coli. We suspect the $250 \mathrm{bp}$ product is a cross-over PCR event between the $70 \mathrm{bp}$ Xanthomonas product and a tRNA gene sequence contaminant in the PerfectMatch, presumably E. coli DNA. Most likely the other end of this product is primed in E. coli DNA on the conserved Ile2 primer. Fortunately, the $250 \mathrm{bp}$ product is of no consequence for this study.

Ideally, for a species-specific diagnostic test, all $X$. albilineans strains should be identical in the part of the tRNA ${ }^{\text {ala }}$-spacer-tRNA ${ }^{\text {ile }}$ region targeted by the Ala 4 primer. To screen for possible major differences between strains of this species, a single-stranded conformation polymorphism gel (SSCP, Hayashi, 1991) was used to resolve products amplified with $\mathrm{Ala} 4+\mathrm{Ile} 2$ from the four $X$. albilineans (MSRI) isolates from Mauritius, isolate CTC293 from Brazil, isolate LA334 from Louisiana, the three CTC isolates from Brazil and ATCC 29186. All isolates yielded products of the same mobility (data not shown), except ATCC 29186, which differs by 2 bases in length relative to the three Brazilian isolates (Table 2). ATCC 29186 was isolated from Paspalum dilatatum in Mauritius and is designated subsp. paspali, whereas all other $X$. albilineans were isolated from sugarcane.

SSCP is sufficiently sensitive for our inference that all strains from sugarcane are probably identical or very nearly identical in this region, as desired for this diagnostic test. Nevertheless, the $X$. albilineans isolates used in this study originated either in Brazil, Mauritius, Florida or Louisiana. They do not represent the worldwide genetic diversity of $X$. albilineans, or even that found within their countries of origin, although variation that would affect Ala4 or Ile2 annealing is unlikely. Confirmation of PCR

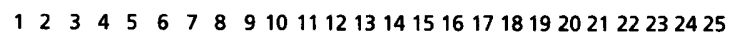

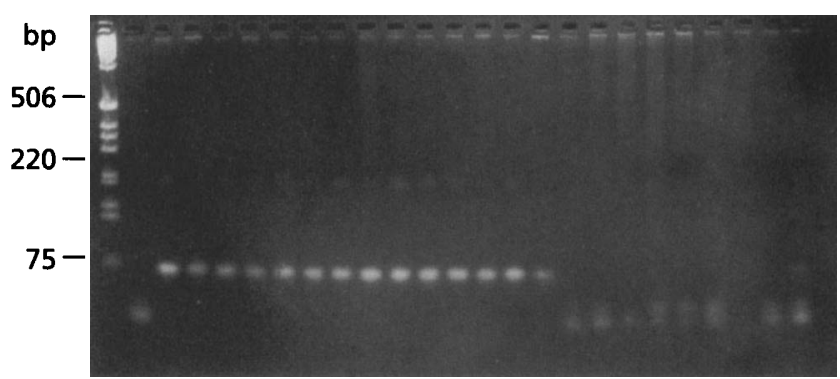

Fig. 6. PCR amplification from the DNA of Xanthomonas isolates using the primer pair Ala4 and Ile2. Reactions were as described in Methods. All reactions included PerfectMatch, $25 \mathrm{ng}$ genomic sugarcane DNA and $1 \mathrm{ng}$ bacterial DNA. The thermal profile was $94^{\circ} \mathrm{C}$ for $20 \mathrm{~s}$ and $70^{\circ} \mathrm{C}$ for $20 \mathrm{~s}$ for 40 cycles. Lanes: 1, $1 \mathrm{~kb}$ standard; 2, sugarcane only; 3-16, $X$ albilineans strains (CTC193, CTC293, CTC393, CTC493, MSRI3201, MSRI3284, MSRI3295, MSRI2905, XaOD1, XaOD3, XaCP2, XaCP3, XaCP4 and ATCC 29186, respectively); 17, X. axonopodis (ATCC $19312) ; 18, X$. campestris pv. campestris (B293); 19, $X$. campestris pv. phaseoli (XP200); 20, X. campestris pv. undulosa (ATCC 35935); 21, X. oryzae pv. oryzicola (X0111); 22, X. campestris pv. pelargonii (XP15); 23, X. campestris pv. celebensis (XC145); 24, X. campestris pv. holcicola (ATCC 13461); 25, X. campestris pv. vasculorum (ATCC 13901).

with our recommended primers as a routine diagnostic tool will only come as a larger number of isolates from a broader geographical range are tested. The test is to be disseminated to sugarcane research stations for this purpose.

Specificity. The specificity of Ala4+Ile2 was tested using 15 isolates of $X$. albilineans, as well as representatives of the closest relatives of $X$. albilineans that are also pathogens of sugarcane (Bradbury, 1984): one isolate of X. campestris pv. vasculorum, one isolate of $P$. rubrisubalbicans, two isolates of $A$. avenae subsp. avenae (formerly $P$. rubrilineans Willems et al., 1992) and one isolate of $P$. syringae pv. lapsa. In addition, species from most major branches of the bacterial phylogenetic tree were analysed (Table 1). All reactions included genomic DNA from sugarcane.

As shown in Fig. 6, the 70 bp product was generally amplified only from $X$. albilineans isolates; no amplification occurred in the sugarcane-only control except the primer dimer product at about $35 \mathrm{bp}$. The primer dimer, when it occurs, confirms that the PCR reaction was viable and acts as a convenient positive control for PCR in samples that do not have bacterial DNA.

Isolates of other Xanthomonas species and X. campestris pathovars (listed in Table 1) were tested and, in general, again no amplification was observed (data not shown). However, a faint product of about $70 \mathrm{bp}$ was sometimes seen in samples containing $X$. campestris pv. vasculorum (Fig. 6, ATCC 13901) and in two Pseudomonas and one Acidovorax species (data not shown). These products did not always occur and when they did occur they were always faint. These PCR products also required the presence of many hundreds of thousands of genomes to 
(a)
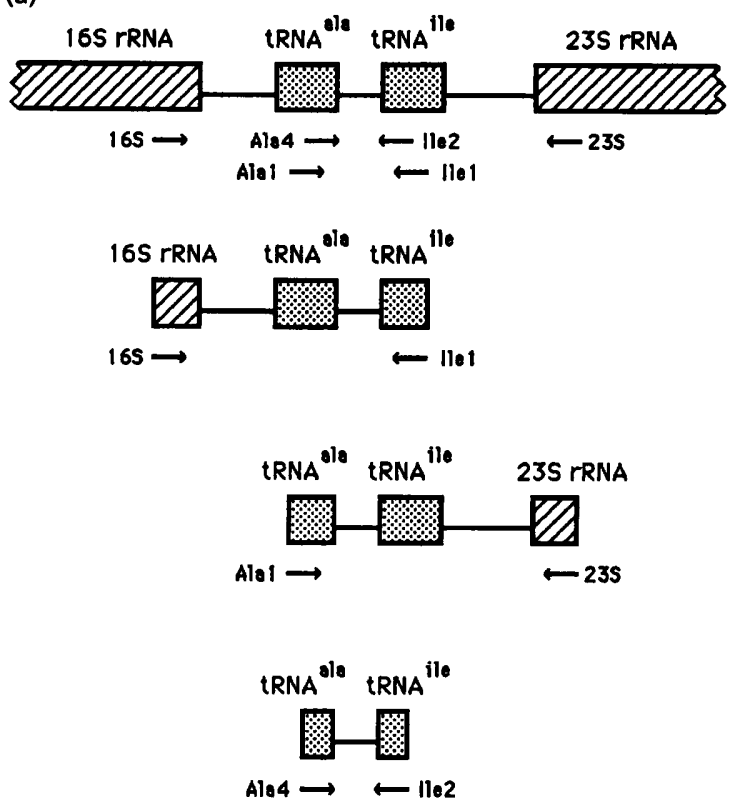

(b)

$$
\frac{165+23 S}{1234} \frac{165+\| l e 1}{234} \frac{\text { Ala } 1+23 S}{234}
$$

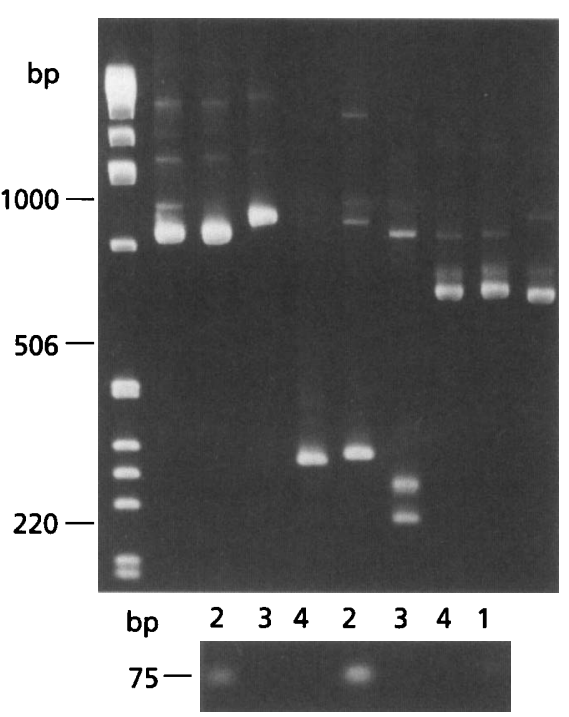

Fig. 7. $P C R$ in the 165 rRNA-23S rRNA spacer region. (a) Diagram of the $16 \mathrm{~S}$ and 235 region showing the location of tRNA ${ }^{\text {ala }}$ and tRNA ${ }^{\text {ile }}$. The location and orientation of the primers are shown that yield products in the nested reactions in (b) and (c). (b) $165+235,16 \mathrm{~S}+1 \mathrm{le} 1$ and Ala $1+23 \mathrm{~S}$ reactions separated on a $2 \%$ agarose gel. Reactions were done as described in Methods. The thermal profile was $94^{\circ} \mathrm{C}$ for $30 \mathrm{~s}, 65^{\circ} \mathrm{C}$ for $30 \mathrm{~s}$ and $72{ }^{\circ} \mathrm{C}$ for $60 \mathrm{~s}$ for 40 cycles. Lanes: $1,1 \mathrm{~kb}$ standard; $2, X$. albilineans CTC193; $3, X$. campestris pv. vasculorum ATCC $13901 ; 4$, P. rubrisubalbicans ATCC 13908. (c) Ala4+lle2 nested reactions using as templates $1 \mu \mathrm{l}$ of a 1/1000 dilution of the $16 \mathrm{~S}+\| l e 1$ or Ala $1+235$ products shown in (b). Lanes as for (b) The reactions were done as described in the Methods and included PerfectMatch. The thermal profile was $94^{\circ} \mathrm{C}$ for $20 \mathrm{~s}$ and $70^{\circ} \mathrm{C}$ for $20 \mathrm{~s}$ for 40 cycles. be detected in 40 cycles (data not shown). Nevertheless, these products could not be completely eliminated even at the highest stringency. Presumably these products derived from inefficient PCR at adjacent tRNA genes that partly but imperfectly matched the primers. While detection of those other species that are pathogenic on sugarcane is equally desirable, it would be better to have a method to distinguish faint positive results due to low levels of $X$. albilineans versus heavier infections from these other possible sources. A strategy to enhance specificity was devised using nested PCR, as explained below.

\section{tRNA ${ }^{\text {ala }}$-spacer-tRNA $A^{\text {ile }}$ is in a 165-23S rRNA spacer region}

The order of tRNA genes is generally conserved within a bacterial genus and sometimes, between related genera (e.g. Jinks-Robertson \& Nomura, 1987). Among the closest relatives of the genus Xanthomonas, the available sequence data showed a locus in all Pseudomonas species examined in which the tRNA ${ }^{\text {ile }}$ and tRNA ${ }^{\text {ala }}$ occurred embedded in the 16S-23S rRNA gene spacer region, but the tRNAs occurred in the opposite order to that found in Xanthomonas: $16 \mathrm{~S}-\mathrm{tRNA}^{\text {ile }}{ }_{\mathrm{t}} \mathrm{RNA}^{\text {ala }}-23 \mathrm{~S}$ (S. D. Tyler, C. A. Strathdee, W. M. Johnson \& K. P. Rozee, unpublished; GenBank accession number L28166). Indeed, the organization we observed in Xanthomonas, tRNA ${ }^{\text {ala }}$ spacer-tRNA ${ }^{\text {ile }}$, was not observed in any of the tRNA gene arrays that have been characterized in eubacteria, except $S$. maltopbilia where $\mathrm{tRNA}^{\text {ala }}$-spacer-tRNA ${ }^{\text {ile }}$ was also located between the 16S rRNA and 23S rRNA genes (S. D. Tyler, C. A. Strathdee, W. M. Johnson \& K. P. Rozee, unpublished; GenBank accession numbers L28148-L28165). Given that this related genus contained the gene order $16 \mathrm{~S}-\mathrm{tRNA}^{\text {ala }}{ }_{-\mathrm{RNA}} \mathrm{RN}^{\text {ile }}-23 \mathrm{~S}$, we suspected that the same order may occur in Xantbomonas. To test this possibility for $X$. albilineans, PCR and nested PCR reactions were performed as outlined in Fig. 7(a). The primary product observed using universal $16 \mathrm{~S}$ and $23 \mathrm{~S}$ rRNA gene primers on the genome of $X$. albilineans was about 1080 bp (Fig. 7b, lane 2). When PCR was performed using a universal $16 \mathrm{~S}$ primer in combination with the Ile1 primer, or the Ala1 primer in combination with a universal $23 \mathrm{~S}$ primer, the most prominent products observed were $340 \mathrm{bp}$ and $815 \mathrm{bp}$, respectively, in $X$. albilineans (Fig. 7b, lanes 5 and 8). If the order of genes is 16StRNA ${ }^{\text {ala }}-\mathrm{TRNA}^{\mathrm{i} \mathrm{ie}_{-}} 23 \mathrm{~S}$, then these products should be amplified by PCR with the nested primers Ala4+Ile2 as was indeed the case (Fig. 7c, lanes 1 and 3). Nested PCR can be expected to be more sensitive than a single PCR reaction so it is entirely possible that 10 or fewer molecules of $X$. albilineans might be detected with this nested PCR assay in the presence of a vast excess of sugarcane DNA.

For species other than $X$. albilineans, the faint PCR products seen when using Ala4+Ile2 on total genomic DNA probably do not derive from the $16 \mathrm{~S}+23 \mathrm{~S}$ region. The order of tRNA ${ }^{\text {ala }}$ and tRNA ${ }^{\text {ile }}$ genes is inconsistent with all characterized Pseudomonas rRNA spacers and the sequence we have for $X$. campestris pv. vasculorum matches very poorly with Ala4 at the critical $3^{\prime}$ end. Presumably, 
these faint products derive from one of the approximately 100 other tRNA genes organized in cistrons throughout a typical eubacterial genome, among which two or three other copies of each of the tRNA ${ }^{\text {ala }}$ and tRNA ${ }^{\text {ile }}$ genes can be expected. Thus, one can expect that after PCR of the $16 S+23 S$ spacer region only $X$. albilineans will present an abundant template for Ala4 + Ile2. This was indeed the case as shown for two examples in Fig. 7(c), lanes 2, 3, 5 and 6 .

In summary, the length of the product from the consensus tRNA primer pair AEU + IEL distinguishes $X$. albilineans from other Xanthomonas species. Pairs of primers based on these adjacent tRNAs gave PCR products that showed length variation that distinguished some Xanthomonas species and pathovars. When one primer included a $X$. albilineans-specific portion of the $\mathrm{tRNA}{ }^{\text {ala }}{ }_{-\mathrm{tRNA}} \mathrm{R}^{\text {ile }}$ spacer region, a PCR product was obtained in $X$. albilineans which allowed sensitive detection of very low levels of $X$. albilineans alone, or in the presence of sugarcane genomic DNA, and in infected sugarcane. Nested PCR produced a diagnostic test highly specific for $X$. albilineans.

The strategy presented could be used to find taxonspecific length polymorphisms at other tRNA loci or in other genera of bacteria. This strategy also has the advantage over other PCR-based methods in that not only is a PCR product present only in a set of related species, but also its size can be taxonomically informative.

\section{ACKNOWLEDGEMENTS}

We thank Mavis Hendson (ICPB, Berkeley, CA), Michael Grisham (USDA-ARS Houma, LA), Jack Comstock (USDAARS, Canal Point, FL) and Mary Simcox (Stratagene Cloning Systems) for providing materials used in this study. We also appreciate Barbara Hass (Plant Pest Exclusion Branch, California Department of Food and Agriculture) for patiently guiding us through the import permit process. We are grateful to Dave Ralph for ribosomal primers, Keira Maiden for technical assistance, and John Welsh and Rita Cheng for helpful discussions. This work was supported by a grant from Copersucar (Piracicaba, Brazil) and the Mauritius Sugar Industry Research Institute (Reduit, Mauritius) to B.W.S.S. M.M. is supported in part by a generous gift from Sidney Kimmel and by NIH grants AI34829, NS33377 and CA68822. Patent pending.

\section{NOTE ADDED IN PROOF}

The specificity of the primer Ala4 and its localization in the ribosomal spacer region has now been utilized in another study for 58 strains of $X$. albilineans (Yong-Bao Pan, USDA-ARS Sugarcane Research Unit, Houma, LA, USA, personal communication).

\section{REFERENCES}

Ausubel, F. M., Brent, R., Kingston, R. E., Moore, D. D., Seidman, J. G., Smith, J. A. \& Struhl, K. (Eds) (1987). Current Protocols in Molecular Biology. New York: John Wiley \& Sons.
Bradbury, J. F. (1984). Genus II. Xanthomonas Dowson 1939, $187^{\mathrm{AL}}$ In Bergey's Manual of Systematic Bacteriology, vol. 1, pp. 199-210. Edited by N. R. Krieg \& J. G. Holt. Baltimore: Williams \& Wilkins.

Comstock, J. C. \& Irey, M. S. (1992). Detection of the leaf scald pathogen, Xanthomonas albilineans, using tissue blot immunoassay, ELISA, and isolation techniques. Plant Dis 76, 1033-1035.

Davis, M. J., Rott, P., Baudin, P. \& Dean, J. L. (1994a). Evaluation of selective media and immunoassays for detection of Xanthomonas albilineans, causal agent of sugarcane leaf scald disease. Plant Dis 78, 78-82.

Davis, M. J., Warmuth, C. J., Rott, P., Catenet, M. \& Baudin, P. (1994b). Worldwide genetic variation in Xanthomonas albilineans. Program and Abstracts of the 4th ISSCT Pathology Workshop, Brisbane, Australia, April 4-9, 1994, p. 28.

Hayashi, K. (1991). PCR-SSCP: a simple and sensitive method for detection of mutations in the genomic DNA. PCR Methods Appl 1 34-38.

Hildebrand, D. C., Palleroni, N. J. \& Schroth, M. N. (1990). Deoxyribonucleic acid relatedness of 24 xanthomonad strains representing 23 Xanthomonas campestris pathovars and Xanthomonas fragariae. J Appl Bacteriol 68, 263-269.

Jinks-Robertson, S. \& Nomura, M. (1987). Ribosomes and tRNA. In E. coli and S. typhimurium, pp. 1358-1385. Edited by F. C. Neidhardt. Washington, D. C.: American Society for Microbiology.

Leite R. P., Minsavage G. V., Bonas U. \& Stall R. E. (1994). Detection and identification of phytopathogenic Xanthomonas strains by amplification of DNA sequences related to the $b r p$ genes of Xanthomonas campestris pv. vesicatoria. Appl Environ Microbiol 60, 1068-1077.

Louws, F. J., Fulbright, D. W., Taylor Stephens, C. \& de Bruijn, F. J. (1994). Specific genomic fingerprints of phytopathogenic Xanthomonas and Pseudomonas pathovars and strains generated with repetitive sequences and PCR. Appl Environ Microbiol 60, 2286-2295.

McClelland, M., Peterson, C. \& Welsh, J. (1992). Length polymorphisms in tRNA intergenic spacers detected by using the polymerase chain reaction can distinguish Streptococcal strains and species. J Clin Microbiol 30, 1499-1504.

Murray, M. G. \& Thompson, W. F. (1980). Rapid isolation of high molecular weight plant DNA. Nucleic Acids Res 8, 4321-4325.

Palleroni, N. J., Hildebrand, D. C., Schroth, M. N. \& Hendson, M. (1993). Deoxyribonucleic acid relatedness of 21 strains of Xanthomonas species and pathovars. J Appl Bacteriol 75, 441-446.

Palleroni, N. J. \& Bradbury, J. F. (1993). Stenotrophomonas, a new bacterial genus for Xanthomonas maltophilia. Int J Syst Bact 43, 606-609.

Ricaud, C. \& Ryan, C. C. (1989). Leaf scald. In Diseases of Sugarcane, pp. 39-58. Edited by C. Ricaud, B. T. Egan, A. G. Gillispie, Jr \& C. G. Hughes. Amsterdam: Elsevier.

Rott, P., Davis, M. J. \& Baudin, P. (1994). Serological variability in Xanthomonas albilineans, causal agent of leaf scald disease of sugarcane. Plant Patbol 43, 344-349.

Seal, S. E., Jackson L. A. \& Daniels M. J. (1992). Use of tRNA consensus primers to indicate subgroups of Pseudomonas solanacearum by polymerase chain reaction amplification. Appl Environ Microbiol 58, 3759-3761.

Tigano-Milani, M. S., Honeycutt, R. J., Lacey, L. A., Assis, R., McClelland, M. \& Sobral, B. W. S. (1995a). Genetic variability of 
Paecilomyces fumosoroseus isolates revealed by molecular markers. $J$ Invert Patbol 65, 274-282.

Tigano-Milani, M. S., Samson, R. A., Martins, I. \& Sobral, B. W. S. (1995b). DNA markers for differentiating isolates of Paecilomyces lilacinus. Microbiology 141, 239-245.

Tsai, C. C., Lin, C. P. \& Chen, C. T. (1990). Characterization and monoclonal antibody production of Xantbomonas albilineans (Ashby) Dawson the causal agent of sugarcane leaf scald disease. Plant Prot Bull 32, 125-135.

Vauterin, L., Swings, J., Kersters, K., Gillis, M., Mew, T. W., Schroth, M. N., Palleroni, N. J., Hildebrand, D. C., Stead, D. E., Civerolo, E. L., Hayward, A. C., Maraite, H., Stall, R. E., Vidaver, A. K. \& Bradbury, J. F. (1990). Towards an improved taxonomy of Xanthomonas. Int J Syst Bacteriol 40, 312-316.

Versalovic, J., Koeuth, T. \& Lupski, J. R. (1991). Distribution of repetitive DNA sequences in eubacteria and application to fingerprinting of bacterial genomes. Nucleic Acids Res 19, 6823-6831.

Welsh, J. \& McClelland, M. (1990). Fingerprinting genomes using PCR with arbitrary primers. Nucleic Acids Res 18, 7213-7219.

Welsh, J. \& McClelland, M. (1991). Genomic fingerprints produced by PCR with consensus tRNA gene primers. Nucleic Acids Res 19, $861-866$.
Welsh, J. \& McClelland, M. (1992). PCR-amplified length polymorphisms in tRNA intergenic spacers for categorizing staphylococci. Mol Microbiol 6, 1673-1680.

Welsh, J., Pretzman, C., Postic, D., Saint-Girons, I., Baranton, G. \& McClelland, M. (1992). Genomic fingerprinting by arbitrarily primed polymerase chain reaction resolves Borrelia burgdorferi into three distinct phyletic groups. Int J Syst Bacteriol 42, 370-377.

Wiedmann-Al-Ahmad, M., Tichy, H.-V. \& Schoen, G. (1994). Characterization of Acinetobacter type strains and isolates obtained from wastewater treatment plants by PCR fingerprinting. Appl Environ Microbiol 60, 4066-4071.

Willems, A., Goor, M., Thielemans, S., Gillis, M., Kersters, K. \& De Ley, J. (1992). Transfer of several phytopathogenic Pseudomonas species to Acidovorax as Acidovorax avenae subsp. avenae subsp. nov., comb. nov., Acidovorax avenae subsp. citrulli, Acidovorax avenae subsp. cattleyae, and Acidovorax konjaci. Int J Syst Bact 42, 107-119. Williams, J. G., Kubilik, A. R., Livak, K. J., Rafalski, A. \& Tingey, S. V. (1990). DNA polymorphisms amplified by arbitrary primers are useful as genetic markers. Nucleic Acids Res 18, 6531-6535.

Received 24 February 1995; revised 17 July 1995; accepted 1 August 1995. 